.K23 $1899 /$

1900 Copy 1

\title{
BIENNIAL REP0RT
}

OF THE

KANSAS

LIVE-S'OCLK SAVITARY COMIIISSSON,

1899-1900.

M. C. CAMPBELL, Wichita, Chairman.

F. H. CHAMBERLAIN, Sedan, Secretary.

W. F. COWLEY, Columbus, Treasurer.

TOPEKA :

W. Y. MORGAN, State Printer.

1901. 



\title{
BIENNIAL REPORT
}

OF THE

\section{KANSAS}

\section{LIVESTIOCK SANITARY COUNISSSOON,}

\author{
1899-1900.
}

M. C. CAMPBELL, Wichita, Chairman.

F. H. CHAMBERLAIN, Sedan, Secretary.

W. F. COWLEY, Columbus, Treasurer. 


$$
5+k^{20^{2}} 3^{3}
$$

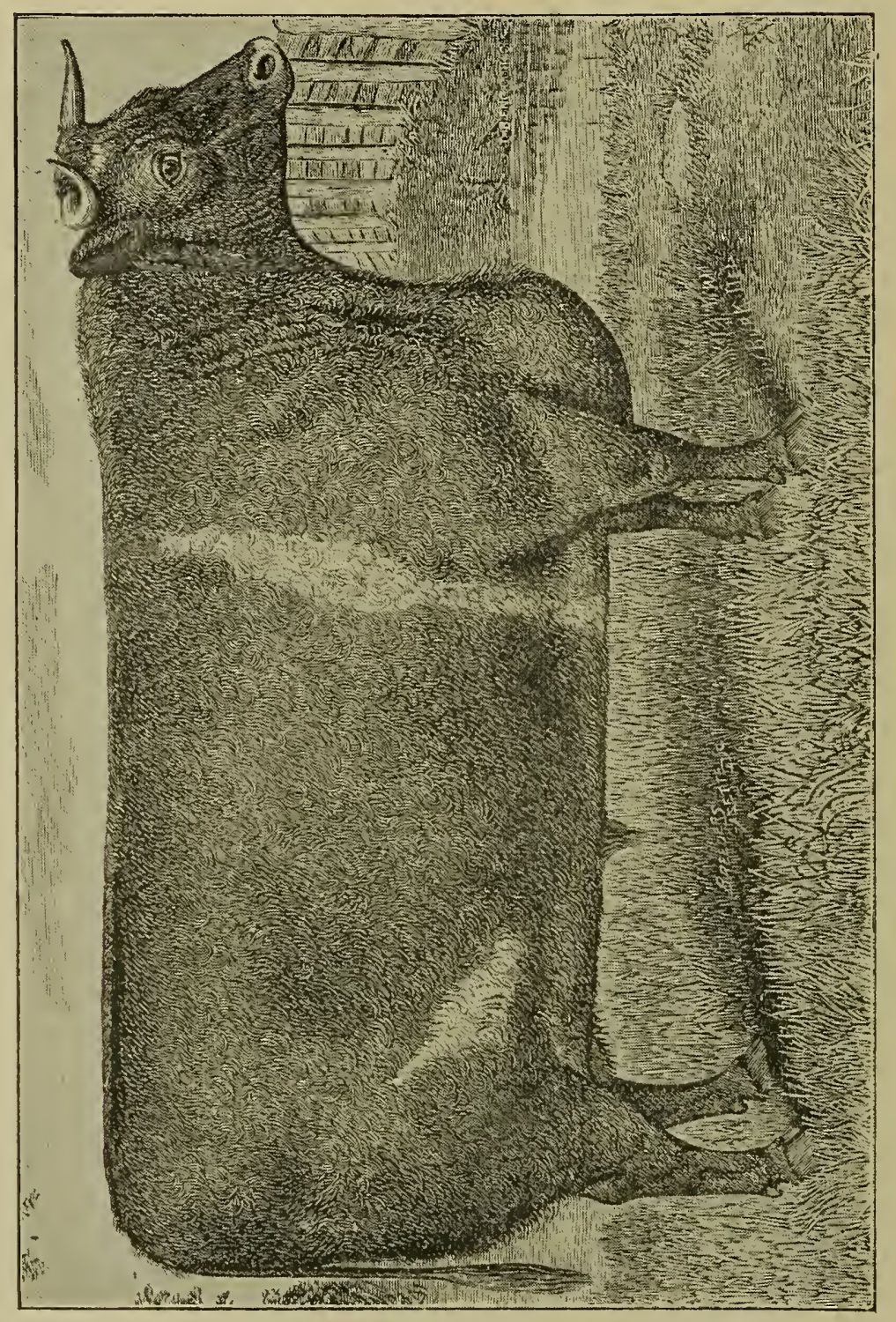

D. of D.

JAN $3 \quad 1918$ 


\section{REPORT.}

Topeka, Kan., December 31, 1990.

To his Excellency, Governor Stanley:

SIR-In compliance with section 2, chapter 142, of the General Statutes of 1897, we, the Live-stock Sanitary Commission of the state of Kansas, have the honor to submit to your consideration our biennial report for the years 1899 and 1900.

The governor having appointed M. C. Campbell, of Wichita, and F. H. Chamberlain, of Chautauqua county, Kansas, to succeed John Bryden and J. B. Beal, whose time of office had expired, and the said appointments having been duly confirmed by the state senate, the members proceeded, upon the 21 st day of February, 1899, to reorganize the board by the election of M. C. Campbell, as chairman, Taylor Riddle, secretary, and F. H. Chamberlain, treasurer.

The season being at hand for the movement of cattle from the Southwest territories to Kansas and other Northern states, the following proclamation and rules and regulations were submitted to the governor for his signature:

\section{PROCLAMATION QUARANTINING CERTAIN LOCALITIES ON ACCOUNT OF} TEXAS FEVER.

Topeka, February 25, 1899.

WherEas, As per "regulations concerning cattle transportation," by the United States department of agriculture, under date of December 19, and special orders of December 20,1898, modifying quarantine line for the year 1899, that a contagious and infectious disease, known as splenic or Southern ferer, exists among cattle in the United States in the area hereinafter set forth:

Now, Therefore, I, W. E. Stanley, governor of the state of Kansas, for the purpose of preventing the introduction and spread of said disease in this state, do, by virtue of the authority in me vested, hereby proclaim that any cattle imported into this state from all that country lying south or below a line beginning at the northwest corner of the state of California; thence east, south and southeasterly along the boundary line of said state of California to the southeastern corner of said state; thence southerly along the western boundary line of Arizona to the southwest corner of Arizona; thence along the southern boundary lines of Arizona and New Mexico to the intersection of the latter line with the international boundary line at the Rio Grande river; thence southeasterly along the said international boundary line to the southwest corner of the county of Pecos; thence following the western boundary of Pecos county to the southeast corner of Reeves county; thence following the boundary line between the counties of Pecos and Reeves to the Pecos river; thence southeasterly, following the Pecos river, to the northwest corner of Crockett county; thence east along the northern boundary of Crockett and Schleicher counties to the southeastern cor- 
ner of Irion county; thence north along the eastern boundary of Irion county to the northeast corner of said county; thence north to the southern boundary of Coke county; thence west to the southwest corner of Coke county; thence north along the western boundary of Coke county to the southern boundary of Mitchell county; thence east to the southeastern corner of Mitchell county; thence north along the eastern boundary of Mitchell county to the northeast corner of said county; thence east along the southern boundaries of Fisher and Jones counties to the southeast corner of Jones county; thence north along the eastern boundary of Jones county to the northeast corner of said county; thence east along the southern boundary of Haskell county to the southeast corner of said county; thence north along the western boundary lines of Throckmorton and Baylor coun. ties to the northwest corner of Baylor county ; thence east along the southern boundary of Wilbarger county to the southeast corner of said county; thence north along the eastern boundary of Wilbarger county to the Red river; thence continu. ing in a northwesterly direction along the course of said river and the northern boundary of Texas to the southeast corner of Greer county; thence northerly, following the course of the North Fork of the Red river to its intersection with the southern boundary line of Roger Mills county, along the western boundary lines of the Apache, Comanche and Kiowa Indian reservations; thence east along the southern boundary lines of Roger Mills and Washita counties to the intersection with the boundary line of the Wichita Indian reservation on the Washita river; thence north along the western boundary line of said reservation to its northwest corner at its intersection with the Canadian river in the county of $\mathrm{G}$; thence in a southerly direction along the course of said river and the northern boundary of the Wichita Indian reservation to the northeast corner of said reservation; thence easterly along the southern boundary of Canadian county to the southeast corner of said county; thence north along the eastern boundary lines of Canadian and Kingfisher counties to the northeastern corner of Kingfisher county ; thence east along the southern boundary of $O$ (Garfield) county to the southeast corner of said county; thence north along the eastern boundary of $\mathrm{O}$ (Garfield) county to the northeast corner of said county; thence east along the southern boundary line of $K$ county to the west line of the Ponca Indian reservation; thence north along the west line of said reservation to the northwest corner of said reservation; thence east along the northern boundary of the Ponca Indian reservation to the Arkansas river; thence in a northerly direction following the course of the said river to its intersection with the thirtyseventh parallel of north latitude at the southern boundary line of Kansas; thence along said southern line east to the southeast corner of said state; thence southerly along the western boundary line of Missouri to the southwestern corner of Missouri; thence easterly along the southern boundary line of Missouri to the western boundary line of Dunklin county; thence southerly along the said western boundary to the southwestern corner of Dunklin county; thence easterly along the southern boundary line of Missouri to the Mississippi river; thence southerly along the western boundaries of the counties of Dyer and Lauderdale to the southwest corner of Lauderdale county, on the Mississippi river; thence easterly along the northern boundary of Tipton county to the northeast corner of said county: thence northerly and easterly along the western and northern boundaries of Haywood county to the northeast corner of said county; thence easterly along the northern boundary lines of Madison, Henderson and Decatur counties to the northeast corner of Decatur county; thence south along the eastern boundary of Decatur county to the northwest corner of Wayne county; thence easterly along the northern boundary lines of Wayne and Law- 
rence counties to the northeastern; corner of Lawrence county; thence south along the western boundary of Giles county to the southwestern corner of said county; thence east and north along the southern and eastern boundaries of said county to the northwestern corner of Lincoln county; thence easterly along the northern boundaries of Lincoln and Moore counties to the northeast corner of Moore county; thence north along the western boundary lines of Coffee and Cannon counties to the north west corner of Cannon county; thence easterly to the northeast corner of Cannon county; thence south to the intersection of the eastern boundary line of Cannon county with the boundary of Warren county; thence easterly and northerly along the northern boundary lines of Warren, White and Cumberland counties to the northeast corner of Cumberland county; thence southerly along the eastern boundary lines of Cumberland, Rhea and James counties to the northwest corner of Bradley county; thence northerly and southerly along the northern boundary lines of Bradley and Polk counties to the northeast corner of Polk county; thence south along the eastern boundary line of Polk county to the southeast corner thereof at the southwestern corner of North Carolina; thence east along the southern boundary lines of the counties of Cherokee, Clay, Macon, Jackson and Transylvania to the southeast corner of the county of Transylvania; thence northwesterly along the eastern boundary line of Transylvania county to the southwest corner of the county of Buncombe; thence easterly along the southern boundary line of Buncombe county to the summit of the Blue Ridge mountains; thence in a northeasterly direction, following the eaid mountains to their intersection with the northern boundary line of the state of North Carolina; thence east along the southern boundary of Virginia to the south western corner of Patrick county; thence northerly along the western boundaries of Patrick and Franklin counties to the western boundary of Bedford county; thence in a southeasterly and northeasterly direction along the southern and eastern boundaries of Bedford county to the James river; thence following the James river to the southeastern corner of Charles City county; thence northerly and easterly along the western and northern boundaries of James City county to the western boundary of Gloucester county at the York river: thence southerly and northerly along the southern and eastern boundaries of Gloucester county to the northeastern corner of said county; thence easterly and southerly along the northern and eastern boundaries of Mathews county to the southeastern point of said county; thence south to the northern boundary of Elizabeth City county; thence westerly and northerly along the boundaries of Elizabeth City and Warwick counties to the James river; thence sou theasterly along the course of the said river to the northwest corner of Norfolk county; thence south along the western boundary of said county to its intersection whith the northern boundary of North Carolina; thence east along the southern boundaries of Norfolk and Princess Anne counties to the Atlantic ocean.

And no cattle from the above-described infected area shall be allowed to come into the state of Kansas, except as provided by the rules and regulations of the Live-stock Sanitary Commission of this state.

\section{RULES AND REGULATIONS.}

RULE 1. That part of the stock-yards of Kansas City west of the Kaw river, and known as the quarantine division, together with all chutes and approaches thereto, is hereby set apart for the reception and handling of "Southern cattle" and such other cattle as arrive at the Kansas City stock-yards in violation of the sanitary rules and regulations of this Commission.

RULE 2. No cattle from area described in governor's proclamation of Febru- 
ary 25,1899 , shall be brought into the state of Kansas except when shipped by rail for immediate slaughter, or during the months of November and December, and when brought in during the above-named months the unanimous consent of the Live-stock Sanitary Commission of the state must be first secured, and the cattle prove to be free from infection after careful inspection. When coming at any other time, except in the months of November and December, they shall be governed by the following rules:

RULE 3. Each car carrying cattle, and carrying the same in the course of transportation from said infectious area into or through the state of Kansas, must have a placard firmly attached, stating in bold letters, "This car contains Southern cattle"; and the way-bill of the said car shall have marked plainly on the face thereof the words "Southern cattle."

RULE 4. On unloading Southern cattle at points of destination, or for feed, water, and rest, at any stock-yards in Kansas, certain chutes, alleys and pens must be set apart for their exclusive use, and whenever any Southern cattle that have been unloaded in Kansas shall be reshipped to other points of destination, the cars in which said cattle are to be reloaded must be placardad and way-bills thereof marked plainly "Southern cattle."

RULE 5. Cars that have carried infectious cattle shall be thoroughly disinfected before being loaded with non-infectious cattle. Such disinfection shall be by removing all litter and manure, washing the cars, the feeding- and wateringtroughs with water until clean, saturating the walls and floors of the cars with a solution made by dissolving four ounces of chloride of lime to each gallon of water; or, disinfect the cars with a jet of steam under a pressure of not less than fifty pounds to the square inch. All litter and manure taken from the cars when disinfected must be stored where no cattle can come in contact with it, or so treated as to destroy all means of infection.

RULE 6. Where a pasture lies on both sides of quarantine, all of said pasture shall be treated as being south or below said quarantine line described in the governor's proclamation of February 25., 1899.

RuLE 7. All cattle coming from that portion of Texas and Oklahoma lying north and west of the quarantine line and the territories of Arizona and New Mexico are hereby prohibited from entering Kansas without the owner or person in charge first complying with the following regulations: Cattle to enter Kansas from the area hereinbefore described in this paragraph must show by affidavit of owner or person in charge, made before a county clerk or a notary public, that the cattle to enter Kansas are free from cattle-ticks (Boophilus bovis), have been exclusively kept since Jannary 1, 1899, north and west of the quarantine line designated in the governor's proclamation of February 25, 1899; and that the cattle have not come in contact with Southern cattle or a trail made by them since January 1,1899 . Also, give number, kinds and brands or marks of cattle. But before any catttle from the above-described territory shall be admitted into the state of Kansas, they shall be subject to an actual inspection by an authorized agent or inspector appointed by the Live-stock Sanitary Commission of Kansas, and if upon inspection they are found free from Texas-fever cattle-ticks (Boophilus bovis), as described in the affidavit herein required of the owners or of parties in charge of such cattle, and surrendering to the inspector the affidavit heretofore made by said owners or persons in charge of such cattle, the inspector shall issue a permit for all cattle so inspected. One copy of said permit must be attached to way-bill stub accompanying such cattle, and the owners or parties in charge of said cattle will also be furnished with a copy of said permit. W'here 
cattle are inspected on range, they must be first cut out, counted, and be ready for immediate shipment.

RulE 8. Where cattle are driven into Kansas from area described, they shall comply with rule 7 as to affidavits, but no permit will be issued until said cattle have reached the Kansas state line.

RulE 9. An agent for the state of Kansas shall be appointed by the Live-stock Sanitary Commission for any public stock-yards whenever said Commission shall deem such agent necessary to protect the health of the live stock of the state and to prevent the spread of contagious diseases. Such agent shall be paid by the owners of the stock-yards where he may be located. His compensation shall be fixed and his duties prescribed by the Live-stock Sanitary Commission of Kansas.

Rule 10. It shall be the duty of the managers or persons in charge of any stock-yards in Kansas to keep the said yards in proper sanitary condition for the protection of the health of live stock entrusted to their care, and to cleanse and disinfect all yards and pens, chutes and alleys, at such times as may be deemed necessary by this Commission or its authorized agents.

Rule 11. The townships of Garden, Lowell, and Spring Valley, in Cherokee county, Kansas, are hereby specially quarantined, and no cattle shall be admitted to other parts of Kansas or the state of Missouri from above-named townships, except they shall first be inspected by an agent or inspector of this Commission, and found to be free from Texas-fever ticks (Boophilus bovis), and when allowed to go shall be accompanied by a permit issued by said agent or inspector. Cattle coming from Missouri, if accompanied with health bills required by the sanitary board of said state, shall be admitted to Kansas without further requirements.

RuLE 12. Notice is hereby given that cattle infested with the Boophilus bovis, or Southern cattle-tick, disseminate the contagion of splenic or Southern fever (Texas fever). Therefore, cattle infested with the Boophilus bovis tick shall be considered as infectious cattle, and shall be subject to the rules and regu. lations governing the movement of Southern cattle.

Rule 13. That cattle from the counties of Jasper, Newton, McDonald, Barry, Stone, Taney, and Ozark, and the township of Thayer in Oregon county, all in the state of Missouri, are prohibited from entering Kansas except when accompanied by a permit issued by an authorized agent or inspector of the state of Missouri or Kansas, certifying that all of said cattle desiring to enter Kansas are free from Texas-fever ticks (Boophilus bovis), and that said cattle have not been south of the state line of Missouri or Kansas since January 1, 1899.

RuLE 14. That the states of Kansas and Missouri have agreed to maintain joint inspection at the Kansas City-and St. Joseph stock-yards, and that the same territory scheduled in the rules and regulations for the state of Kansas and prohibited from entering said state, except under restrictions contained in said rules and regulations, are also scheduled by the state of Missouri, and will not be allowed to enter that state except when complying with the same rules and regulations as those governing cattle desiring to enter Kansas, as set forth in rules and regulations of February 27, 1899.

RULE 15. This issue takes precedence over the rules and regulations of February 27,1899 , in all matters treated therein, and is to be followed by transportation companies and others desiring to bring cattle into Kansas from territory scheduled herein.

RulE 16. All railroads, live-stock transportation and stock-yard companies and their employees, and all other persons, are hereby forbidden to transport, 
drive or in any way handle cattle in Kansas, except in compliance with the foregoing rules, under the pains and penalties of the following statute:

SEc. 21. Any person who shall violate, disregard, or evade, or attempt to violate, disregard, or evade, any of the . . . rules, regulations, orders or directions of the Live-stock Sanitary Commission establishing and governing quarantine, shall be deemed guilty of a misdemeanor, and, upon conviction thereof, shall be fined in any sum not less than $\$ 100$ nor more than $\$ 5000$. (Chapter 2, Session Laws of 1884 .)

Done at our office, in Topeka, Kan., April 28, 1899.

By order of the Live stock Sanitary Commission.

M. C. Campbell,

F. H. Chamberlain,

TAYLOR Riddle,

Members.

N. B. - Note change in admission of cattle from territories of Arizona and New Mexico. Permits issued by Colorado inspectors will be legal and accepted on all shipments destined for points in Kansas and Missouri where shipments come through the state of Colorado.

A fee of one-half cent per head will be charged on all cattle coming through the state of Colorado to points in Kansas and Missouri, to cover expense of collecting and returning records of such shipments and for issuing permits for same.

Inspectors were then appointed for the following places, to wit: J. W. Hamilton, stock-yards, Kansas City, Mo.; F. M. Bricker, Fort Worth, Tex.; R. G. Ross, Amarilla, Tex.; D. R. Streeter, Kiowa, Kan.

The order of inspection in Kansas was changed to the inspection of all cattle before entering the market yards of Kansas City, thereby giving them freedom to go from the yards to any states or territories without further inspection. This we believe to be better than to allow them to go into the yards and inspect them out, as had been formerly done. By this method, with nearly two years of business, there has not been a single case of infection known to have gone out of the market yards of Kansas City, and, by rigid inspection at all ports of entry, there has not been a single herd of cattle passed a Kansas inspector which carried infection into the state.

There was an outbreak of fever in the pasture known as the Hull \& Dillon pasture, near Pittsburg, Kan., on June 5, 1899, which came from a herd of Southern cattle permitted to come to the slaughter-houses of Hull \& Dillon, at Pittsburg, for immediate slaughter. The parties violated the trust that was reposed in them by taking these cattle to their pasture, thereby disseminating infection in the neighborhood of the same, and resulting therefrom was the death of some seven or eight animals. By promptly placing the cattle, pastures and trails under quarantine little trouble resulted therefrom.

We also had an outbreak of fever on August 2, 1899, at the pastures of Holmes Brothers, near Clements, Kan., in the herd known as the Page herd of cattle, from Clarendon, Tex. These cattle came from a country of high altitude, where there was no question as to 
the health of the animals; from this fact, we have every reason to believe that this infection was carried into the state by a car originating on the Fort Worth \& Denver railroad, which had not been properly disinfected after hauling Southern cattle.

June 2, 1899, F. H. Chamberlain received information that fortyeight head of cattle in John Foote's pasture, six miles east of Caneyville, were infected with Texas fever, this information being given by Col. Dan McCuningham, the government inspector. Mr. Chamberlain immediately investigated the charges and found them to be true, and telegraphed the county attorney of Montgomery county, John Callahan, who issued a warrant for John Foote, who had brought the cattle into the state contrary to the rules and regulations of the State Sanitary Commission; said John Foote pleaded guilty and paid a fine of $\$ 213$.

There was brought into the state of Kansas from the territory scheduled in the above rules and regulations, during the year 1899, 616,000 cattle, all of which were inspected by Kansas inspectors and found free from infection.

As the season advanced the movement of cattle increased, and it became necessary to appoint additional inspectors at the state-line points. for the purpose of inspecting cattle that came to Kansas by way of the trail. There being no appropriation by the state for this purpose, and the sanitary board, realizing the great necessity of preventing infectious animals from coming into the state, believed that it was proper to appoint inspectors for the trail herds and fix a moderate fee, which should be collected from the owners of the cattle, for the purpose of compensating the inspectors for their services. This was done, and the whole amount thus collected aggregated $\$ 1225.16$, which was prorated among the inspectors, as follows: Charles B. Collins, Baxter Springs; J. W. Chamberlain, Coffeyville; L. Musgrove, Arkansas City; A. M. Colson, Caldwell; J. W. Crewdson, Kiowa; J. P. Campbell, Englewood, and George De Kow, Liberal, Kan.

J. W. Hamilton, our inspector at Kansas City, was paid by the Kansas City stock-yards; F. M. Bricker, inspector at Fort Worth, Tex., was paid by the stock-yards of Fort Worth and the railroads; R. G. Ross was paid by the Fort Worth \& Denver and the Pecos Valley railroads at Amarilla, Tex.; and D. R. Streeter, of Kiowa, was paid by the Southern Kansas in Oklahoma.

Of the cattle offered for shipment at the Fort Worth stock-yards, destined for points in Kansas and the Kansas City stock-yards, 3350 were found to be infectious by Inspector Bricker, and were either turned back below quarantine line at Fort Worth, or sent to the Southern division of the Kansas City stock-yards,, cars properly 
tagged "Southern cattle"; during the same year, among the cattle that were offered for shipment at Caldwell, 450 were found to be infectious by Inspector Colson, and denied admission into Kansas. Among the cattle offered for shipment in Oklahoma over the Southern Kansas railroad, 1540 were found to be infectious by Inspector Streeter at Gage and Woodward and denied bills of health, and were returned to their places of origin in Oklahoma. Infectious cattle to the number of 5500 were offered for shipment to Montana points, and the same would have been unloaded in shipping pens for feed and rest in Kansas except for the timely action on the part of C. L. Brown, the inspector for this Commission, who was stationed on the Forth Worth \& Denver railroad in Texas. He made the discovery of Texas-fever infection in this herd and prevented them from being shipped; these cattle were sent back below quarantine line into the Chickasaw nation. Other small herds were found to be infectious in the same territory by the same inspector: and upon examination were denied bills of health.

Thus will be seen that, through the efforts and vigilance of the Kansas inspection, 10,840 infectious cattle were prevented from reaching the pastures, feed lots and shipping pens of the state.

The above refers to the board's work on the admission of cattle only. Much time has been given to horses and mules that have been afflicted with glanders in different portions of the state, the most of which have been voluntarily destroyed by the owners after being convinced that their animals were afflicted with the glanders. Hence, no moneys of the state have been spent for that purpose, beyond the expenses of the state veterinarian in making examinations of the same. This completes a synopsis of the board's work for 1899 .

Much time was given in January and February of the year 1900 to the investigation of the territory bordering upon the quarantine lines running from Missouri to the west and southwest of the Oklahoma and Kansas lines, through Oklahoma; also, through Texas to the Rio Grande; after which rules and regulations were promulgated governing the movement of Southern cattle, which are the same as those published February 25, 1899, as shown in the publication for that year, in the beginning of this report. Also, a proclamation and rules and regulations governing the movement of cattle from certain Eastern states, scheduled in the first section of the following proclamation, published March 1, 1900 :

\section{PROCLAMATION BY THE GOVERNOR.}

Whereas, The Live-stock Sanitary Commission of the state of Kansas, on March 1, 1900, adopted the following rules and regulations:

WhEREAS, The Live-stock Sanitary Commission of the state of Kansas have ascertained that a great many of the breeding and dairy cattle in the states of 
Maine, New Hampshire, Vermont, Massachusetts, Rhode Island, Connecticut, New York, New Jersey, Delaware, Pennsylvania, Ohio, Kentucky, Tennessee, Indiana, Michigan, Illinois, Wisconsin, Minnesota, Iowa and Nebraska are infected with a contagious and infectious disease in cattle known as tuberculosis, and that some of said cattle are being shipped into the state of Kansas for breeding and dairy purposes, it is therefore ordered:

1. That from and after this date it shall be unlawful for any cattle to be shipped, driven or transported from the above-named states into the state of Kansas for breeding or dairy purposes; provided, however, that shipments may be made from such states into the state of Kansas for breeding and dairy purposes after said cattle have been examined and found free of tuberculosis, and a permit and bill of health given by a veterinarian of the United States bureau of animal industry, or a veterinarian acting under the order and direction of the live-stock sanitary board of any of the above-named states, and the certificate so given by such veterinarians shall be given in duplicate, the original of which shall be forwarded to the secretary of the Live-stock Sanitary Commission; Topeka, Kan., and the duplicate given to the railroad company, to be attached to the bill of lading for said cattle. And no railroad company shall accept any such cattle, nor bring nor ship any such cattle in to the state of Kansas from any of the above-named states, for breeding or dairy purposes, without the certificate and bill of health herein provided for; and no railroad company shall accept from its connecting lines any cattle shipped in violation of this provision.

2. Provided, however, that native cattle of the state of Nebraska may be moved into the state of Kansas upon the owner or person in charge thereof making affidavit, stating, in substance, that said cattle are natives of said state, and that said cattle have not been in any of the states above named for a year immediately preceding the making of said affidavit. Said affidavit shall be made before some officer authorized to administer oaths, and the above affidavit so made shall be given in duplicate, the original of which shall be forwarded to the secretary of the Live-stock Sanitary Commission, Topeka, Kan., and the duplicate shall be given to the owner or person in charge of said cattle, to be attached to the bill of lading for said cattle, or carried by the owner or person in charge when driven in; and no railroad company shall accept any such cattle for shipment, nor bring nor ship any such cattle into the state of Kansas for breeding or dairy purposes from the state of Nebraska, nor accept from its connecting lines any cattle shipped in violation of this provision.

3. Cattle brought into Kansas from any of the above-named states for the purpose of exhibition at county, district or state fairs shall not be subject to the above regulations; provided, however, that in the event sales shall be made from such exhibition, and the cattle destined to points in Kansas, the animal sold shall be submitted to the tuberculin test before the sale is consummated or the cattle moved or shipped to their destination. In case the test should show any such animals to be affected with tuberculosis, a permit for shipment to any point in this state shall not be granted.

4. All railroad, live-stock, transportation and stock-yard companies, and their employees, and all other persons, are hereby forbidden to transport, drive or in any way handle cattle in Kansas, except in compliance with the foregoing rules, under the pains and penalties of the following statute:

SEc. 21. Any person who shall violate, disregard, or evade, or attempt to violate, disregard, or evade, any of the tary Commission establishing and gorerning quarantine, shall be deemed guilty of a misdemeanor, and, upon conviction thereof, shall be tined in any sum not less than $\$ 100$ nor more than $\$ 5000$. (Chapter '2, Session Laws of 1834.)

Sheriffs, constables and police officers in Kansas are hereby directed to enforce these regulations, and to report any violations of same to this Commission.

In Testimony WHeREOF, I hereby set my hand, and cause to be affixed the great seal of the state of Kansas.

[SEAL.] Done at Topeka, Kan., this 5th day of March, 1900.

By the governor :

W. E. Stanley,

Geo. A. Clark,

Governor of Kansas.

Secretary of State. 
About April 1 the time expired for which Taylor Riddle was appointed, and W. F. Cowley, of Cherokee county, was appointed by Governor Stanley to succeed Mr. Riddle as member of the sanitary board. Immediately following the appointment of Mr. Cowley the board reorganized, and M. C. Campbell was reelected chairman, F. H. Chamberlain, secretary, and W. F. Cowley, treasurer.

The following-named inspectors were duly appointed: J. W. Hamilton, Kansas City, to succeed himself ; F. M. Bricker, at Fort Worth; R. G. Ross, Fort Worth \& Denver railway in Texas; L. M. Dakin, for the Pecos Valley \& Northeastern in Texas; and D. R. Streeter, Southern Kansas in Oklahoma.

During the year 1900 there were offered for shipment 326,918 cattle destined for Kansas pastures, all of which were inspected by agents of this Commission at points above mentioned, among which were 7630 infectious cattle, disćovered by our inspectors, to wit: R. G. Ross, Fort Worth \& Denver; F. M. Bricker, at Fort Worth, Tex.; and D. R. Streeter, on the Southern Kansas in Oklahoma - all of which were either turned back to points below quarantine line or shipped to the Southern division of the Kansas City stock-yards, with the cars properly tagged as Southern cattle.

July 1, information reached this board that Texas fever had made its appearance in some pastures near Jonesburg, Chautauqua county, Kansus. Upon receipt of this information, F. H. Chamberlain immediately proceeded to the district and the pastures in which the diseased cattle were reported to be, and there found some of the cattle to have already died, and others sick and infectious. The infection showed that the disease was unmistakably Texas fever, and that the infected cattle were in danger of communicating the disease to others. The diseased cattle and all other cattle in the vicinity which had been exposed or suspected of having been exposed to infection from the diseased cattle above mentioned were quarantined and isolated from the uninfected herds and pastures of that vicinity.

Under our direction, the sick cattle and those bearing the Texasfever tick (Boophilus bovis) were dipped with crude petroleum from the oil-wells in that vicinity. New fences were built, and every precaution taken to prevent the spread of the disease.

About the same time Texas fever was discovered in what is known as the Connor pasture, about four and one-half miles east of Sedan, in said Chautauqua county, and reported to this board; whereupon F. H. Chamberlain, immediately after attending to the cattle in the vicinity of Jonesburg, as above mentioned, proceeded to the Connor pasture, and finding Texas fever present there, proceeded in like manner to establish a quarantine and isolate the infected and exposed cattle of that vicinity. 
Between the $2 \mathrm{~d}$ and 6 th of July, the exact date being unknown to this board, Texas fever was discovered in the herds of one Langdon, about three miles west of Chautanqua Springs, in Chautauqua county, Kansas, and was concealed by the owner of the cattle, and an effort made to dispose of said infected cattle by running them onto the Kansas City market. These cattle were by the owners shipped to Kansas City, and there discovered by Jos. Boozer, inspector B. A. I., and J. W. Hamilton, state inspector. Whereupon W. F. Cowley, of this board, being present when said infectious cattle were discovered, proceeded to and did establish immediately a like quarantine over the cattle remaining in said pasture and those exposed to infection, F. H. Chamberlain, the resident member, being absent attending to official duties in other localities at this time.

A careful investigation showed that this fever, in all of the three localities above mentioned in Chautauqua county, was introduced by cattle brought across the southern line of Kansas in violation of the statutes and the quarantine regulations of this board.

The officers of the law in Chautauqua county are in full possession of all the facts which are obtainable in connection with these cases, and this board does not at this time deem it advisable to enter further into the written details of these transactions, on account of criminal prosecutions, some of which are now pending and others which may be instituted in the near future. It is sufficient for the information of your excellency and the public to state, that while the cattle in the infected pastures and those exposed to infection therefrom numbered more than a thousand head, yet, under the treatment of the cases as this board was able to do, the disease was not permitted in any case to extend beyond the pastures in which it was originally discovered, and the whole number of cattle lost in all three of the quarantine districts above referred to was only 142 .

This experience in Chautauqua county demonstrates to the satisfaction of this board that Texas fever can be controlled and effectively stamped out by the prompt establishment of proper quarantine and sanitary regulations over the stock and pastures in which the disease makes its appearance.

On the 17th of July, as a further precaution against the possible spread and extension of Texas fever in Chautauqua county, this board established a quarantine over the townships of Harrison, Hendricks, Belleville, and Little Caney; they being the four townships in Chautauqua county, Kansas, bordering on the south line of the state of Kansas, which quarantine was rigidly enforced under directions of this board up to the 28th day of August, 1900, when it appeared to the satisfaction of this board that the outbreak of Texas fever in 
Chautauqua county was fully and perfectly under control and the necessity of such quarantine no longer existed. The quarantine was, therefore, on that date, by order of this board, raised. The cattle in the infected pastures and those exposed to infection were kept under quarantine until the 1st day of December, when they were released according to law.

Upon information given to the sanitary board, that cattle to the number of six, carrying Texas-fever ticks, were driven into the state by one J. C. Marney, of Cherokee county, Kansas, W. F. Cowley immediately investigated the charges, and, finding them to be true, on September 12, placed all cattle, pastures and trails under quarantine. W. F. Cowley swore out a warrant for the arrest of J. C. Marney, who, upon his pleading guilty, was fined $\$ 100$ and costs. On October 30 information reached W. F. Cowley, of this board, that eleven head of cattle had been shipped from Fort Smith, Ark., to Fort Scott, Kan., bearing Texas-fever ticks to a great number. W. F. Cowley promptly placed said cattle, pastures, trails, and the Missouri Pacific stock-yards, in said vicinity, under quarantine, and so held them until December 1, except the Missouri Pacific stock-yards, which were thoroughly and immediately disinfected and released.

By carefully following this report, it will be seen that, out of 953.758 cattle offered for shipment to Kansas and Northern points in two years, 18,470 were found to be carrying infection, and were either denied shipment or consigned to the Southern division of the Kansas City stock-yards, thus preventing the spread of Texas-fever infection broadcast over the state.

For the reasons stated below, the following proclamation was published by Governor Stanley, suspending the rules and regulations. requiring the inspection of cattle from Eastern states suspected of having tuberculosis :

\section{PROCLAMATION RAISING QUARANTINE.}

Whereas, On the 13th day of October, A. D. 1900, the Live-stock Sanitary Commission of the state of Kansas made the following recommendation, to wit:

\section{To the Governor of the State of Kansas:}

Pending a decision of the supreme court of the state of Illinois as to the legality of the rules and regulations of the state governing the movement of cattle, and requiring the application of tuberculin to ascertain whether or not the cattle are afflicted with tuberculosis, the live-stock sanitary commission of Illinois have suspended their rules and regulations; the live-stock sanitary commission of the state of Missouri have done likewise; and at a meeting of the Livestock Sanitary Commission of Kansas, held at our office October 11, 1900, it was unanimously decided to recommend to your excellency to suspend the rules and regulations promulgated by you March 1, 1900, scheduling the following states, to wit: Maine, New Hampshire, Vermont, Massachusetts, Rhode Island, Connecticut, New York, New Jersey, Delaware, Pennsylvania, Ohio, Kentucky, Tennessee, Indiana, Michigan, Illinois, Wisconsin, Minnesota, Iowa, and Nebraska, and, by so doing, to permit cattle from said scheduled states to enter Kansas without restrictions. (Signed) M. C. Campbell, Chairman. 
Now, Therefore, I, W. E. Stanley, governor of the state of Kansas, in accordance with said recommendation of the Live-stock Sanitary Commission, do hereby proclaim and declare that the quarantine established March 1, 1900, as aforesaid, against the introduction of cattle into the state of Kansas from the said states of Maine, New Hampshire, Vermont, Massachusetts, Rhode Island, Connecticut, New York, New Jersey, Delaware, Pennsylvania, Ohio, Kentucky, Tennessee, Indiana, Michigan, Illinois, Wisconsin, Minnesota, Iowa, and Nebraska, be and the same is hereby raised, and that said rules and regulations promulgated March 1, 1900, be suspended, from and after this date.

In Testimony Whereof, I have hereunto subscribed my name and caused to be affixed the great seal of the state of Kansas. Done at Topeka, [SEAL.] this 17th day of October, A. D. 1900.

W. E. Stanley, Governor.

Attest: Geo. A. Clark, Secretary of State.

CHANGES IN THE LAW.

As it is necessary to appoint inspectors to guard against the introduction of live stock into our state that are liable to introduce contagious disease, this Commission would recommend that an appropriation of $\$ 10,000$ per annum be made to cover salaries of such inspectors and the salaries or per diem and expenses of this Commission.

Judging from the past, this would probably cause the board to employ inspectors for such times during the year as the board, in their discretion, might deem necessary. It would also include a sufficient appropriation to cover expenses of a stenographer or clerk to keep the record in the office of this Commission, and the further expenses of a contingent fund to defray postage, express, telegrams, and such sums as would be necessary to defray the expenses of the state veterinary surgeon, when technical knowledge should be desired by the board.

And we would further recommend that an inspection fee be charged upon cattle desiring to enter Kansas under the rules and regulations of this Commission, to reimburse the state for the expenses of inspection and examination on the herds so brought in.

Taking the past as a criterion, we believe that two cents per head would raise a sufficient amount to cover the expenses so incurred.

It will be seen from the foregoing recommendations that we are of the opinion that different legislation to promote and insure the efficiency of this Commission is necessary, and this necessity further arises on account of various imperfections and inconsistencies of chapters 139 and 142, volume 2, of the General Statutes of 1897. These inconsistencies and imperfections are apparent upon the examination of the chapters referred to, and arise, perhaps, from the fact that the body of these chapters as now embraced in our statutes was enacted nearly twenty years ago, when the conditions of our livestock interests in Kansas were entirely different from what they are 
now, and was less thoroughly understood in its true light by the legislature and our citizens in the live-stock business at that time.

Various imperfections have been called to the attention of the legislature since the enactment of this section, and from time to time sections have been repealed and others amended, until there has grown to be in our law many inconsistencies relative to the organization and management of this board and its duties.

We think that these laws should by the next legislature be revised to suit existing conditions and present interests, or they should be repealed and new laws passed for the government and regulation of this board.

It is also a fact that has developed in our experience during the past two years, that the penal sections of chapter 139 are insufficient to effectively prevent the introduction of diseased cattle along the southern line of the state of Kansas. By reason of the inability of the officers of the state law to properly punish persons guilty of the introduction of diseased cattle into the state of Kansas, there has been a considerable loss and damage to the live-stock in the border counties.

It is, therefore, in our judgment, of the utmost importance that the laws regulating the introduction of cattle into the state and prescribing punishment for their violation should be reformed so as to make their provisions more definite and the punishment for their violation more severe and certain.

There is perhaps no district in the state of Kansas where it is as difficult to enforce laws and regulations designed for the prevention of the introduction of diseased cattle into the state as Cowley and Chautauqua counties; the government quarantine line being the south line of the state of Kansas permits diseased cattle to be shipped for grazing purposes into the Osage reservation, which lies immediately south and adjoining such counties. The topography of these counties along the south line of the state is very rough and broken and in many places is covered by a dense growth of scrubby black-jack timber, with nothing but a barb-wire fence, in most places, to separate the state from the infected pastures of the Osage reservation, and in many places the line between the state of Kansas and the Osage reservation is not even marked by a barb-wire fence. In the years gone by there has been continually more or less smuggling of cattle across this line in all of the south border counties east of the Arkansas river, and it is very difficult to apprehend and punish those who violate the quarantine laws of this state by the introduction of cattle from the Osage reservation.

It is our experience in these matters, and in cases as the above, 
that leads us to the conclusion that this board ought to be provided with additional inspectors, and line riders or detectives, who might continually patrol the danger points a ong the south line of the state.

We are also convinced that the present law establishing an "open season," when cattle may be introduced from south of the quarantine line without inspection, ought to be changed and so modified that no cattle should be admitted from the infected districts, or south of the quarantine line, without inspection under the authority of this board. This we think necessary, for the reason that in certain portions of this state, and particularly the south and southeastern portions, our winters are so mild that ticks brought in on Southern cattle during the "open season" are not destroyed, but live over through the winter, multiply, and spread infection in Kansas herds the following summer. There is no means at the disposition of this board by which we can even approximately discover how much of the losses by Texas fever which our stockmen have suffered in the past is due to infection brought into our state during what is known to our law as the "open season"; but this board is satisfied that a great deal of such trouble and loss is due to infection thus introduced.

We further think that this board should have the power and authority to establish and designate several points along the south line of Kansas where cattle might be presented for inspection and admission, by those desiring to bring stock from south of the south line of this state into Kansas, and that, when such points of inspection and entry are designated and established by this board, our law should provide a very severe penalty for the bringing of any cattle across the south line of this state without inspection, or at any points other than the ones designated as aforesaid by this board.

We believe that, with such modifications of the law as above recommended, we shall be able to meet the present demands of the cattle interests in our state, and, with the additional appropriation referred to in this report, that this board will be able during the next two years effectively to protect the live-stock interests of this state from all character of infection and contagion, and thereby fully accomplish the purposes for which this board has been created and maintained.

Respectfully submitted.

M. C. CAMPBELL.

F. H. CHAMBERLAIN.

W. F. COWLEY. 


\section{VETERINARIAN'S REPORT.}

\section{TEXAS FEVER.}

(Spanish fever, southern cattle plague, splenic apoplexy, tick fever, infective Hcemoglobinamia.)

Texas fever is an infective disease of cattle caused by the introduction into the blood of minute animal parasites (Hcrmatozoa, Howmamcebce). These micro-organisms are carried by ticks (Boophilus bovis), which act as the infecting media. Being thus introduced into the blood, the parasites invade the colored blood-cells, which they destroy in large numbers. The disease occurs in two forms one acute (in summer), the other chronic (in the fall).

\section{SYMPTOMS.}

The disease is produced in ten to fifteen days after the young ticks become attached to the skin. The time required for the development of the young ticks from the eggs is two to six weeks, according to the temperature. In acute cases eighty. to ninety per cent. of the diseased animals die in five to six days. In other cases death may be delayed for two weeks or more. Relapses are common, so that the disease may last for months. The temperature in pronounced cases rises to 105 to 108 degrees from the normal of 101 to 102 degrees. There is dullness and weakness; the animal loses its appetite, lies down, leaves the herd. The secretion of milk decreases, and there may be constipation or diarrhea. Breathing becomes difficult, and rapid emaciation occurs. In the last stages the urine becomes red from the large amount of blood-coloring matter which it contains. In suspected cases, careful search should be made for the ticks. They are most likely to be found on the inside of the thigh, the flanks, or around the udder. The young ticks are very small, and the search must be thorough.

TREATMENT.

Medicinal treatment is of no practical value. If good ground to suspect the disease to be Texas fever exists, the Live-stock Sanitary Commission should be notified immediately.

\section{GLANDERS - FARCY.}

(Rotz, Rotzkrankheit.)

Glanders is an infective disease which affects chiefly horses and mules. It is transmissible to the human being. If the alterations caused by the disease are mainly localized in the mucous lining of 
the respiratory system, the term "glanders" is applied. If, on the other hand, the skin is chiefly affected, it is usually designated "farcy." Both forms are produced by the same germ (the Bacillus mallei). The two sets of lesions may coexist. Other diseases do not "run into glanders," although debilitating diseases, such as distemper, may render an animal more susceptible to the infection. It may be acute or chronic in its course.

\section{SYMPTCMs.}

Only ten per cent. of the cases in horses are acute; it is, however, the usual form in mules and donkeys. Its invasion is usually insidious in horses. Weeks or even months may elapse before the symptoms become visible. Bleeding at the nose, without apparent cause, is a very suspicious indication. A case of chronic glanders has been known to have a duration of seven years; acute cases usually terminate fatally in two weeks or less. In the latter type, the disease begins with shivering and high fever; the temperature may rise to 108 degrees from the normal of 99 to 100 degrees. There is a discharge from the nose of mucus and pus, which later becomes tinged with blood. The lining of the nose is covered with nodules and ulcers; these may appear in two or three days. The breathing is difficult and rattling or roaring sounds may be heard. There may be swelling of the skin, the formation of "buttons" and ulcers; cord-like swelling of the lymphatic vessels; swelling of the glands between the branches of the lower jaw and at the throat. Loss of appetite occurs early and diarrhea sets in. Great weakness and emaciation usher in a fatal termination.

In chronic cases, unfortunately, the signs are frequently quite obscure. They consist of a discharge from one or both nostrils. It is, usually slight and variable - at first watery, later thicker and yellowish. It smells badly only in advanced cases, when it may be mixed with pus and blood. In addition, the glands between the branches of the jaw are enlarged, hardened, less movable, and not usually sensitive to pressure. Ulcers may appear on the lining of the division between the two chambers of the nose. Frequently the ulcers or nodules are too far back to be seen.

Later the animal loses condition, coughs, becomes weak and shortwinded, appears to have rheumatism, and may bleed at the nose now and again. Fever is usually very moderate and not constant. In glanders of the skin (farcy), nodules from the size of a hemp seed to that of a pea appear. Deeper-seated nodules may be much larger. They may burst and form ulcers. The lymphatics form knotted cords. The lymph glands become enlarged and hard. In many cases the symptoms resemble so much those of non-contagious diseases such as 
nasal gleet (catarrh), diseased teeth, and lymphangitis, that the unprofessional observer cannot make the distinction. Even the qualified veterinarian must resort in obscure cases to what is known as the Mallein test to make a diagnosis.

\section{TREATMENT.}

Medicinal treatment should not be used. It is of no practical value and the person handling the animal is taking a great risk. If reasonable suspicion exists, separate the animal, avoid risk of contagion so far as possible, and notify the Commission, if no qualified veterinary surgeon can be consulted conveniently.

\section{BLACKLEG.}

(Rauschbrand, Charbon, Sarcophysema hamorrhagica bovis.)

This is an infective disease, attacking usually young cattle, preferably those in good thrifty condition. It is typically a soil or ground disease, being produced by the blackleg bacillus, which is able to multiply either outside or within the body. It is not contagious in the sense of being transmitted directly from one animal to another. Animals receive the germ from the soil or on food.

SYMPTOMS.

The disease is rapid, usually terminating fatally within twentyfour to forty-eight hours after infection. The symptoms are restlessness, loss of appetite, fever, lameness, and stiffness. Soon swellings appear, especially on the thigh, quarter, shoulder, breast, or throat. The sweilings increase greatly in size in a few hours, and the fever rises to 107 to 108 degrees. When the hand is passed over the skin of swellings a characteristic crackling sound is produced. Cases in which the mouth or throat is affected may succumb in a very short time.

\section{PREVENTION.}

Treatment, medicinal or surgical, is of no practical utility. Fortunately, preventive measures are possible and remarkably effective. Infected ground should not be used for pasturing, but for cropping. Carcasses should not be skinned and should be burned, if possible. Finally: and most important, young cattle in districts where the disease exists should be vaccinated, and thus rendered immune. For the past two years, a vaccine (or virus) for this purpose has been prepared by the department of veterinary science and zoology at the state agricultural college, Manhattan. It is issued to stock-owners who apply for it at a nominal charge (one cent per dose), to defray expense of packing and postage. A bulletin showing the use and value of this preventive in over 100,000 head of cattle will be issued early in 1901 . 


\section{TUBERCULOSIS.}

This is one of the oldest known diseases of our domestic animals, and is also the most wide-spread. It is an infective disease, caused by the Bacillus tuberculosis. It has been most frequently observed in man, cattle, pigs, and birds; less often in horses, dogs, cats, etc. There are not sufficient statistics as to its frequence in sheep and goats.

Its great importance rests on the fact that it is widely disseminated; that it is infectious, being transmissible from animals to man (and vice versa); and that it is usually incurable, and usually very insidious in its course. Much harm has undoubtedly been done by the erroneous view that the disease is generally inherited, and by failure to take into account its infectious character. It is only rarely inherited, though the predisposition evidently is. The vast majority of cases in man are the result of infection, usually by his fellow man. A relatively small number are caused by the ingestion of meat, . milk and milk products of diseased animals. To this must be added the losses through death and barrenness among cattle.

It would be quite impossible to give any adequate account of the disease in the space at my disposal here. For a full description of tuberculosis, see bulletin No. 79, issued by the veterinary department of the experiment station. The problem of preventing the increase and of gradually eliminating tuberculosis from the cattle of the state is too large and many-sided for discussion in this report. Without venturing on any wholesale radical measures, one or two suggestions as to what can and should be done may not be out of place. These are as follows: (1) The slaughter of all animals which show the disease distinctly; (2) careful destruction of carcasses of such animals, and disinfection of places where they have been kept; (3) extended use of the tuberculin test, especially among dairy and pure-bred herds. The formulation and enforcement of ordinances providing for regular inspection and testing of dairy cattle can probably be best invested in the local boards of health in towns and cities. Owners of purebred cattle should have them tested. Animals which react, but appear healthy, may be isolated and bred from. The calves should be separated and fed on the milk of healthy cows. Newly purchased stock should be tested before being introduced into the herd. In this way the disease can be gradually eliminated without serious loss.

\section{SHEEP SCAB.}

Sheep scab is a contagious disease caused by a species of mites. The common scab is produced by the species technically termed Psoroptes communis ovis. It is large enough to be seen by the naked eye. 
The adult male is about one-fiftieth of an inch long and one-eightieth of an inch broad; the female is a little larger, being about onefortieth of an inch long and one-sixtieth broad. They can best be recognized by placing some of the crust from the margin of the affected spots on dark paper and examining with a hand lens. If placed in sunshine or otherwise warmed for a few minutes they creep about and are more easily seen.

SYMPTOMS.

The common scab mite invades chiefly those parts which are most thickly covered with wool, $i$. e., the back, sides, rump and shoulders. The bites produce intense itching, irritation, and inflammation. This, and the rubbing of the affected animal, causes exudation of blood serum and the formation of crusts or scabs, under which the parasites live. The wool becomes matted together, loosened, and shed. The irritation is increased by exercise and by housing. The disease tends to spread rapidly over the diseased animal and is communicated readily to other animals. Unless proper remedies are used, a loss of ten to eighty per cent. may result. The mortality is highest in fall and winter, when sheep are closely housed, or are kept under unfavorable conditions and are not well nourished. The vitality of the mite when separated from sheep is not yet exactly determined. Without food and exposed to dry air, they commonly die in about fifteen days. Under other conditions, they may live at least six weeks.

\section{TREATMENT AND PREVENTION.}

The best treatment is dipping. One of the best dips for fresh outbreaks is :

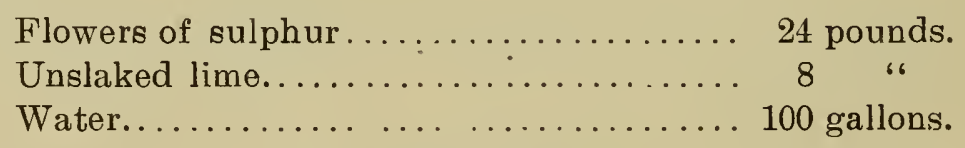

In more severe cases, it may be necessary to increase the amount of sulphur to thirty-three pounds and the lime to eleven pounds. The lime is slaked to the consistence of paste and the sulphur is then well stirred in. The mixture is then boiled for two hours or more in twenty-five to thirty gallons of water and stirred up. Pour off into a tub or barrel and allow plenty of time for sediment to settle. Draw off the clear fluid and add warm water to make 100 gallons. The sediment must not be used for dipping. It may be sprinkled about to kill parasites and disinfect. Dipping is, of course, more efficient after shearing. It must be repeated in ten days. The dip should have a temperature of 100 to 110 degrees F. Each sheep should be kept in it two minutes. Diseased spots may be scraped or scrubbed to insure killing the mites. After dipping sheep should not be returned to 
their old, infected quarters. The bureau of animal industry lays down the following important rules:

1. Scabby sheep should never be driven upon a public road.

2. Sheds in which such sheep have been kept should be thoroughly cleaned, disinfected, and aired, and should be left unused for at least a month (better two months) before healthy sheep are placed in them.

3. Fields in which such sheep have been kept should stand vacant at least a month (better six to eight weeks).

For further information, reference may be made to bulletin No. 21, "Sheep Scab," Bureau of Animal Industry, Washington, D. C.

S. SISSON, Veterinarian. 


